\title{
VIOLENCE AMONG FEMALE HEALTH CARE WORKERS
}

\author{
By \\ El sharkawy SA and Mondoor WR \\ Department of Community Medicine and Occupational Health, Faculty of \\ Medicine for Girls, Al Azhar University, Cairo, Egypt \\ Corresponding author: El sharkawySA.Email: safaa.abdelfattah@azhar.edu.eg \\ Submit Date: 2021-02-01 Revise Date: 2021-03-10 Accept Date: 2021-03-21 \\ DOI: $10.21608 /$ ejom.2021.60622.1222 \\ Authors' contribution: Authors contributed equally to this work.
}

\begin{abstract}
Introduction: Healthcare workers (HCWs) are at risk for workplace violence (WPV). It is a serious problem in both developed and developing countries and has a great negative impact on the well-being of HCWs and on the quality of the health system. Aim of Work: To determine the prevalence, pattern, associated factors and impacts of WPV among female HCWs at Al-Zahraa University Hospital and to detect the causes and seek out suggestions to prevent such incident. Materials and Methods: A cross-sectional study was conducted over 4 months from September to December 2019 at Al-Zahraa University Hospital using a standardized questionnaire. The sample size was 312 physicians and nurses. Results: The prevalence of violence was $66.3 \%$ among the studied HCWs with statistically significant higher prevalence among nurses (72.5\%) than physicians $(61.9 \%)$. Verbal violence was the most recurrent type $(62.3 \%)$ followed by the physical type $(19.8 \%)$. Patient relatives and friends were the most frequent perpetrators $(63.3 \%)$. Emergency room was the most common place for violence $(42.5 \%)$. Violent incidents result in physical, psychological impacts and job dissatisfaction. There was significant association of violence with the marital status and the work shift ( $p$ value $<0.05$ ) with no significant association of violence with age, occupation and duration of employments ( $p$ value $>0.05$ ). Low socioeconomic status of patients, shortage of medical equipment and medicine and inadequate security were the most frequently suggested causes of violence. Conclusion and Recommendations: WPV is highly prevalent among the studied HCWs particularly the verbal one and resulted in physical, psychological and work related effects; that highlights the need to develop management strategy to overcome WPV against HCWs. Provision of medical equipment, medicine, security measures, legislation and to restrict public access to examination rooms were the most frequently suggested preventive measures.
\end{abstract}

Key words: Work place violence, Physicians, Nurses, Health care workers, Al-Zahraa University Hospital. 


\section{Introduction}

Workplace violence (WPV) was defined as "incidents where staff are abused, threatened or assaulted in circumstances arising out of, or in the course of their employment- (ILO, ICN, WHO and PSI, 2003).Workplace violence may be physical and nonphysical. Physical violence is harsh and painful action against others that lead to physical harm. It involves pushing, beating, biting, slapping, stabbing, kicking and strangling (Pandey et al., 2018). Non-physical violence includes verbal abuse, threats, intimidation and sexual harassment (Alkorashy and $\mathrm{Al}$ Moalad, 2016).

Healthcare workers are at an increased risk for workplace violence. Violence in the health care setting occurs four times more often than violence in any other private-sector industry. It is a serious problem in both developed and developing countries and has a great negative impact on the well-being of HCWs and on the quality of the healthcare service provided to the patients (Cheung and Yip, 2017).

Patients and their relatives are the most common perpetrators of violence in health care settings. They may behave aggressively either because of illness, unsatisfied treatment plan, or availability of weapons among patients or relatives. They may feel frustrated and angry as a result of the patient's circumstances (Hamdan and Hamra, 2015).There are other perpetrators of violence in health care settings as colleagues (e.g. staff member, administrators and supervisor). These could be attributed to negative communication of HCWs with their colleagues due to competition, long working hours and intensity of psychosocial situation (Yigitbas and Genc, 2019).

There are many contributing factors that affect the prevalence of violence among HCWs. These factors may be related to patients or HCWs as age, gender, marital status, job category and their work experiences or related to the workplace environment as overcrowded and unsuitable waiting halls, improper environmental design and inadequate security (Abdellah and Salama, 2017).

Health care workers who are exposed to violence may suffer from impairment of physical and mental well-being which leads to decreased job satisfaction, loss of confidence, absenteeism, and burnout with negative consequence on work productivity, patient safety and overall quality of 
patient care (Basilua et al., 2015).

The incidence and prevalence of violence against $\mathrm{HCW}$ s were considered by several studies worldwide. In the USA, it was found that $74 \%$ of HCWs experienced violence occasionally, $19 \%$ frequently, and $2 \%$ always in a workplace violence survey done in most regions of the US (Boafo and Hancock, 2017). In Japan, the prevalence of workplace violence was 36\% (Park et al., 2015). The prevalence was $28 \%$ among nurses working in public hospitals and primary health care centres in Iran (Fallahi-Khoshknab et al., 2016).Many studies were conducted in the Arabic region to investigate the workplace violence among HCWs. In Jordan, the prevalence was $76 \%$ among nurses working in Emergency departments (Fujita et al., 2012). In a study conducted in Palestine, about $80 \%$ of the HCWs were exposed to at least one type of violence (Hasan et al., 2018). In Egypt, the prevalence varied. Abdellah and Salama (2017) found that $59.7 \%$ of $\mathrm{HCWs}$ in Emergency department in Ismailia were exposed to WPV during the preceding year.

In spite of some studies conducted in different areas in Egypt like Ismailia, Tanta and Mansoura, there is still need to study this alarming hazard particularly in Cairo, the capital of Egypt. So, the current study was conducted.

\section{Aim of Work}

To determine the prevalence, pattern, associated factors and impacts of work place violence among female health care workers at Al-Zahraa University Hospital and to detect the causes and seek out suggestions to prevent such incident.

\section{Materials and Methods}

Study design: It is a cross-sectional analytical study.

Place and duration of the study: This study was conducted over 4 months from September to December 2019 at AlZahraa University Hospital which located in Al- Abbasya district in Cairo. The hospital staff was nearly1630 physicians and nurses distributed in various surgical and medical units, out-patient clinics and the emergency department.

Target population: The target group was female physicians and nurses who were working in the Emergency department, different inpatient departments, outpatient clinics and special units in the studied hospital and who worked at least for six months and agreed to participate in the study. 
Administrative employees, labourers and male HCWs were excluded from the study as many of the questionnaire items did not apply to their jobs.

Sample size: the sample size was calculated according to certain statistical formula (Roasafot, Inc., 2004) with 95\% confidence limit, 5\% confidence interval and expected prevalence of violence $50 \%$. It was found to be 312 participants. They were selected by proportional allocation from the main list of hospital employees by systematic random sampling.

Study methods: An English version of a standardized questionnaire sheet (ILO, ICN, WHO and PSI, 2003) regarding WPV in the health sector was used for collecting data in English through personal interview with each participant to guarantee high response. It included:

- General data as age, marital status, detailed occupational history including work experience, job title and direct physical contact (e.g. washing, turning and lifting) with patient or not.

- Information related to exposure to violence in the preceeding 12 months and its frequency at the work place, types of violence, reactions to violence and the impact of the accident on the victims.

- Information related to response, reporting and modified questions about the causes and preventive suggestions.

\section{Consent}

Verbal consent was obtained from participants of the study after clarification of the aim of the study and ensuring confidentiality of data.

\section{Ethical Approval}

All the necessary approvals for conducting the research obtained from the Ethical Committee, Faculty of Medicine for girls, Al - Azhar University.

\section{Data Management}

Statistical analyses were carried out by using SPSS version 16. Descriptive statistics as mean, standard deviation and range were used to describe quantitative data while frequency and percentage were used for qualitative one. The association of socio-demographic characteristics of the participants and workplace violence were investigated by using Chi-square test. $p$ value of $<0.05$ was considered to be statistically significant. 


\section{Results}

Table (1): Socio demographic data of the studied female HCWs and exposure to violence.

\begin{tabular}{|c|c|c|}
\hline Characteristics & $\begin{array}{c}\text { Total }=\mathbf{3 1 2} \\
\text { No }\end{array}$ & $\%$ \\
\hline $\begin{array}{l}\text { Age group/ years } \\
20-24 \\
25-29 \\
30-35 \\
>35 \\
\text { Mean } \pm \text { SD } \\
\text { Range }\end{array}$ & $\begin{array}{c}64 \\
132 \\
71 \\
45 \\
29.0 \pm 6.1 \\
20-49\end{array}$ & $\begin{array}{l}20.5 \\
42.3 \\
22.8 \\
14.4\end{array}$ \\
\hline $\begin{array}{l}\text { Marital status } \\
\text { Single } \\
\text { Married }\end{array}$ & $\begin{array}{l}165 \\
147\end{array}$ & $\begin{array}{l}52.9 \\
47.1\end{array}$ \\
\hline $\begin{array}{l}\text { Occupation and job title } \\
\text { Nurse / Nursing specialist } \\
\text { House officer } \\
\text { Resident doctors } \\
\text { Lecturer/ Assistant professors }\end{array}$ & $\begin{array}{c}131 \\
61 \\
79 \\
41\end{array}$ & $\begin{array}{l}42.0 \\
19.6 \\
25.3 \\
13.1\end{array}$ \\
\hline $\begin{array}{l}\text { Duration of employment } \\
6 \text { months }-4 \text { years } \\
5-10 \text { years } \\
>10 \text { years } \\
\text { Mean } \pm S D \\
\text { Range }\end{array}$ & $\begin{array}{c}194 \\
57 \\
61 \\
5.7 \pm 5.7 \\
1-25 \\
\end{array}$ & $\begin{array}{l}62.2 \\
18.3 \\
19.6\end{array}$ \\
\hline $\begin{array}{l}\text { Working shifts } \\
\text { Yes } \\
\text { NO }\end{array}$ & $\begin{array}{c}236 \\
76\end{array}$ & $\begin{array}{l}75.6 \\
24.4\end{array}$ \\
\hline $\begin{array}{l}\text { Exposure to violence } \\
\text { Yes } \\
\text { NO }\end{array}$ & $\begin{array}{l}207 \\
105 \\
\end{array}$ & $\begin{array}{l}66.3 \\
33.6 \\
\end{array}$ \\
\hline $\begin{array}{l}\text { Worried from exposure to violence } \\
\text { Un worried } \\
\text { Mildly worried } \\
\text { Moderately worried } \\
\text { Severely worried }\end{array}$ & $\begin{array}{c}40 \\
79 \\
123 \\
70\end{array}$ & $\begin{array}{l}12.8 \\
25.3 \\
39.4 \\
22.4\end{array}$ \\
\hline
\end{tabular}

Table (1) showed that the age of the studied HCWs ranged from 20 to 49 years with mean and SD 29.0 \pm 6.1. More than one half (52.9\%) was single and $42.0 \%$ of the studied HCWs were nurses. As regards duration of employment, it ranged from 
6 months to 25 years with mean and SD 5.7 \pm 5.7 . Regarding the working schedule, about three quarters $(75.6 \%)$ of the studied HCWs had work shift. Of the examined HCWs $66.3 \%$ were exposed to violence. Nearly two thirds were moderately to severely worry from exposure to work place violence.

Table (2): Prevalence of violence and its characteristics among the HCWs exposed to violence (207).

\begin{tabular}{|c|c|c|c|c|c|}
\hline Characteristics of violence & $\begin{array}{c}\text { Total } \\
\text { No }(\%)\end{array}$ & $\begin{array}{c}\text { Physicians } \\
\text { No }(\%)\end{array}$ & $\begin{array}{l}\text { Nurses } \\
\text { No }(\%)\end{array}$ & $\begin{array}{c}\text { Chi } \\
\text { square }\end{array}$ & p value \\
\hline $\begin{array}{l}\text { Prevalence of violence } \\
\text { among different groups \# }\end{array}$ & $207(66.3)$ & $112(61.9)$ & $95(72.5)$ & 3.8 & 0.03* \\
\hline $\begin{array}{l}\text { Frequency of occurrence \# } \\
1-2 \text { times } \\
2-10 \text { times } \\
\text { More than } 10 \text { times }\end{array}$ & $\begin{array}{l}110(53.1) \\
65(31.4) \\
32(15.5)\end{array}$ & $\begin{array}{l}63(56.2) \\
29(25.9) \\
20(17.9)\end{array}$ & $\begin{array}{l}47(49.5) \\
36(37.9) \\
12(12.6)\end{array}$ & 7.6 & 0.05 \\
\hline $\begin{array}{l}\text { Type of violence } \\
\text { Physical } \\
\text { Verbal } \\
\text { Bullying /mobbing } \\
\text { Sexual harassments } \\
\end{array}$ & $\begin{array}{c}41(19.8) \\
129(62.3) \\
31(15.0) \\
6(2.9)\end{array}$ & $\begin{array}{c}17(15.2) \\
73(65.2) \\
19(17.0) \\
3(2.7)\end{array}$ & $\begin{array}{l}24(25.3) \\
56(58.9) \\
12(12.7) \\
3(3.2)\end{array}$ & 3.7 & 0.44 \\
\hline $\begin{array}{l}\text { Place of violence } \\
\text { Internal department } \\
\text { Outpatient clinics } \\
\text { Emergency room } \\
\text { Operation rooms }\end{array}$ & $\begin{array}{l}46(22.2) \\
54(26.1) \\
88(42.5) \\
19(9.2)\end{array}$ & $\begin{array}{l}28(25.0) \\
25(22.3) \\
46(41.1) \\
13(11.6)\end{array}$ & $\begin{array}{c}18(18.9) \\
29(30.5) \\
42(44.2) \\
6(6.3)\end{array}$ & 3.8 & 0.27 \\
\hline $\begin{array}{l}\text { Perpetrators } \\
\text { Patient } \\
\text { Patient relatives/ friends } \\
\text { Colleagues } \\
\text { Unknown visitors }\end{array}$ & $\begin{array}{l}39(18.8) \\
131(63.3) \\
25(12.1) \\
12(5.8) \\
\end{array}$ & $\begin{array}{l}24(21.4) \\
66(59.0) \\
17(15.1) \\
5(4.5) \\
\end{array}$ & $\begin{array}{c}15(15.8) \\
65(68.4) \\
8(8.4) \\
7(7.4) \\
\end{array}$ & 5.63 & 0.22 \\
\hline $\begin{array}{l}\text { Work shift } \\
\text { Morning shift } \\
\text { Evening shift } \\
\text { Night shift }\end{array}$ & $\begin{array}{l}103(49.8) \\
39(18.8) \\
65(31.4)\end{array}$ & $\begin{array}{l}58(51.8) \\
19(17.0) \\
35(31.2)\end{array}$ & $\begin{array}{l}45(47.4) \\
20(21.1) \\
30(31.6)\end{array}$ & 0.65 & 0.7 \\
\hline $\begin{array}{l}\text { Reaction to the violence act } \\
\text { Did nothing } \\
\text { Told the person to stop } \\
\text { Tried to defend oneself } \\
\text { Asked for help } \\
\text { Reported to hospital administration } \\
\text { Request for vacation/transfer }\end{array}$ & $\begin{array}{l}42(20.3) \\
32(15.5) \\
50(24.4) \\
18(8.7) \\
56(27.1) \\
9(4.3)\end{array}$ & $\begin{aligned} 20 & (17.9) \\
17 & (15.2) \\
28 & (25.0) \\
7 & (6.3) \\
34 & (30.4) \\
6 & (5.4)\end{aligned}$ & $\begin{array}{l}22(23.2) \\
15(15.8) \\
22(23.2) \\
11(11.6) \\
22(23.2) \\
3(3.2)\end{array}$ & 4.14 & 0.65 \\
\hline
\end{tabular}

\# Prevalence and frequency during last 12 months

*: Significant 
Table (2) showed that the prevalence of violence was 66.3\% (207/312) among the studied HCWs with statistically significant higher prevalence among nurses $(72.5 \%)$ compared to physicians $(61.9 \%)(\mathrm{p}<05)$. Frequency of occurrence of violence was once or twice among 53.1\%. Verbal violence was the most frequent type $(62.3 \%)$. Regarding the place of violence, Emergency room was the most common place $(42.5 \%)$. Patient relatives and friends were the most recurrent perpetrators (63.3\%). Nearly half (49.8\%) of violence occurred during the morning shift. The HCWs reaction to violence was different; $27.1 \%$ reported the attack to the hospital administration, $24.4 \%$ tried to defend themselves and $20.3 \%$ showed negative reaction in doing nothing. Also, this table showed that there was no statistically significant difference between physicians and nurses regarding frequency, type, perpetrators, place, work shift and reaction to violence $(\mathrm{p}>0.05)$.

Table (3): Impact of violence among the studied HCWs.

\begin{tabular}{|c|c|c|c|c|c|}
\hline Impact of violence & $\begin{array}{c}\text { Total (207) } \\
\text { No }(\%) \\
\end{array}$ & $\begin{array}{c}\text { Physicians(112) } \\
\text { No (\%) }\end{array}$ & $\begin{array}{c}\text { Nurses (95) } \\
\text { No }(\%) \\
\end{array}$ & $\begin{array}{c}\text { Chi } \\
\text { square }\end{array}$ & $\begin{array}{c}\mathbf{p} \\
\text { value }\end{array}$ \\
\hline $\begin{array}{l}\text { Physical effects: } \\
\text { Physical Injuries\# } \\
\text { Sleep disorders } \\
\text { Frequent headache } \\
\text { Irritable colon } \\
\text { Two or more effects together }\end{array}$ & $\begin{array}{c}8(3.9) \\
49(23.7) \\
105(50.7) \\
59(28.5) \\
42(20.3) \\
\end{array}$ & $\begin{array}{l}3(2.7) \\
26(23.2) \\
64(57.1) \\
39(34.8) \\
28(25.0)\end{array}$ & $\begin{array}{c}5(5.3) \\
23(24.2) \\
41(43.2) \\
20(21.1) \\
14(14.7) \\
\end{array}$ & $\begin{array}{c}0.95 \\
0.02 \\
4.01 \\
4.7 \\
3.34 \\
\end{array}$ & $\begin{array}{c}0.2 \\
0.4 \\
\mathbf{0 . 0 3} * \\
\mathbf{0 . 0 2} * \\
\mathbf{0 . 0 4} * \\
\end{array}$ \\
\hline $\begin{array}{l}\text { Psychological effects: } \\
\text { Remembering the incidents } \\
\text { Want to forget the incidents } \\
\text { Feeling afraid and worried } \\
\text { from people }\end{array}$ & $\begin{array}{l}83(40.1) \\
74(35.7) \\
65(31.4)\end{array}$ & $\begin{array}{l}45(40.2) \\
45(40.2) \\
43(38.4)\end{array}$ & $\begin{array}{l}38(40.0) \\
29(30.5) \\
22(23.2)\end{array}$ & $\begin{array}{c}0.001 \\
2.1 \\
5.5\end{array}$ & $\begin{array}{c}0.54 \\
0.9 \\
\mathbf{0 . 0 1} *\end{array}$ \\
\hline $\begin{array}{l}\text { Combined physical and } \\
\text { psychological effects }\end{array}$ & $85(41.1)$ & $50(44.6)$ & $35(36.8)$ & 1.29 & 0.16 \\
\hline $\begin{array}{l}\text { Work effects: } \\
\text { Dissatisfaction with her work } \\
\text { Do not want to go to work }\end{array}$ & $\begin{array}{l}61(29.5) \\
84(40.6)\end{array}$ & $\begin{array}{l}30(26.8) \\
38(33.9)\end{array}$ & $\begin{array}{l}31(32.6) \\
46(48.4)\end{array}$ & $\begin{array}{c}0.84 \\
4.4\end{array}$ & $\begin{array}{c}0.22 \\
\mathbf{0 . 0 2} *\end{array}$ \\
\hline
\end{tabular}

\#: Abrasion, contusion *: Significant

Table (3) showed the physical, psychological impacts and work effects of exposure to workplace violence. Frequent headache and irritable colon were the most common physical impacts of violence among the studied HCWs $(50.7 \%$, $28.5 \%$ respectively) with statistically significant higher frequency among physicians 
$(57.1 \%, 34.8 \%)$ compared to nurses $(43.2 \%, 21.1 \%)$. Also, two or more physical effects were significantly higher among physicians $(25.0 \%)$ compared to nurses $(14.7 \%)$. There was a statistically significant difference between physicians and nurses as regards psychological effects in the form of feeling afraid and worried from people. Do not want to go back to work was the most frequent symptoms related to work effects of violence $(40.6 \%)$ with significant higher prevalence among nurses (48.4\%) compared to physicians (33.9\%).

Table (4): Association of violence with different characteristics .

\begin{tabular}{|c|c|c|c|}
\hline \multirow{2}{*}{$\begin{array}{c}\text { Characteristics } \\
\qquad(\mathrm{No}=\mathbf{3 1 2})\end{array}$} & \multicolumn{2}{|c|}{ Exposed to violence } & \multirow{2}{*}{$\begin{array}{c}\text { Chi square and } \\
\text { p value }\end{array}$} \\
\hline & $\begin{array}{c}\text { Yes }(207) \\
\text { No }(\%)\end{array}$ & $\begin{array}{c}\text { NO (105) } \\
\text { No }(\%)\end{array}$ & \\
\hline $\begin{array}{l}\text { Age group/years } \\
20-24(\mathrm{No}=64) \\
25-29(\mathrm{No}=132) \\
30-35(\mathrm{No}=71) \\
>35(\mathrm{No}=45)\end{array}$ & $\begin{array}{l}42(20.3) \\
85(41.1) \\
46(22.2) \\
34(16.4)\end{array}$ & $\begin{array}{l}22(21.0) \\
47(44.8) \\
25(23.8) \\
11(10.5)\end{array}$ & $\begin{array}{c}2.02 \\
p=0.56\end{array}$ \\
\hline $\begin{array}{l}\text { Marital status } \\
\text { Single }(\mathrm{No}=165) \\
\text { Married }(\mathrm{No}=147) \\
\end{array}$ & $\begin{array}{c}98(47.3) \\
109(54.7) \\
\end{array}$ & $\begin{array}{l}67(63.8) \\
38(36.2) \\
\end{array}$ & $\begin{array}{c}7.58 \\
\mathbf{p}=\mathbf{0 . 0 0 4} * \\
\end{array}$ \\
\hline $\begin{array}{l}\text { Occupation and job title } \\
\text { Nurse } / \text { Nursing specialist }(\mathrm{No}=131) \\
\text { House officer }(\mathrm{No}=61) \\
\text { Resident doctors }(\mathrm{No}=79) \\
\text { Lecturer/Assistant professors }(\mathrm{No}=41)\end{array}$ & $\begin{array}{l}95(45.9) \\
34(16.4) \\
54(26.1) \\
24(6.8)\end{array}$ & $\begin{array}{l}36(34.3) \\
27(25.7) \\
25(23.8) \\
17(16.2)\end{array}$ & $\begin{array}{c}6.5 \\
p=0.08\end{array}$ \\
\hline $\begin{array}{l}\text { Duration of employment } \\
6 \text { months }-4 \text { years }(\mathrm{No}=194) \\
5-10(\mathrm{No}=57) \\
>10(\mathrm{No}=61)\end{array}$ & $\begin{array}{l}123(59.4) \\
37(17.9) \\
47(22.7) \\
\end{array}$ & $\begin{array}{l}71(67.6) \\
20(19.0) \\
14(13.3)\end{array}$ & $\begin{array}{c}3.9 \\
\mathrm{p}=0.14\end{array}$ \\
\hline $\begin{array}{l}\text { Working shift } \\
\text { Yes }(\mathrm{No}=236) \\
\text { NO }\left(\mathrm{No}^{\prime}=76\right)\end{array}$ & $\begin{array}{c}149(72.0) \\
58(28.0)\end{array}$ & $\begin{array}{l}87(82.9) \\
18(17.1) \\
\end{array}$ & $\begin{array}{c}4.47 \\
\mathbf{p}=\mathbf{0 . 0 2} *\end{array}$ \\
\hline $\begin{array}{l}\text { Physical contact with patients } \\
\text { Yes }(\mathrm{No}=174) \\
\mathrm{NO}(\mathrm{No}=138)\end{array}$ & $\begin{array}{l}111(53.6) \\
96(46.4)\end{array}$ & $\begin{array}{l}63(60.0) \\
42(40.0) \\
\end{array}$ & $\begin{array}{c}1.14 \\
p=0.17\end{array}$ \\
\hline $\begin{array}{l}\text { Numbers of working staff } \\
1-5(\mathrm{No}=212) \\
6-10\left(\mathrm{No}^{\circ}=69\right) \\
11-15\left(\mathrm{No}^{\circ}=31\right)\end{array}$ & $\begin{array}{c}141(68.1) \\
46(22.2) \\
20(9.7)\end{array}$ & $\begin{array}{l}71(67.6) \\
23(21.9) \\
11(10.5)\end{array}$ & $\begin{array}{c}0.052 \\
p=0.97\end{array}$ \\
\hline
\end{tabular}

*: Statistically significant 
Table (4) showed that the prevalence of violence was statistically significant higher among married HCWs (54.7\%) and among those who had working shift (72.0\%). There was no significant association of violence with age, occupation, duration of employment, physical contact with patients and the numbers of working staff among the studied HCWs ( $p$ value $>0.05$ ).

Table (5): Health care workers suggestions about reasons and preventive measures for violence.

\begin{tabular}{|l|c|c|c|}
\hline \multicolumn{1}{|c|}{ Possible reasons } & $\begin{array}{c}\text { Total =312 } \\
\text { No (\%) }\end{array}$ & Suggested preventive measures & $\begin{array}{c}\text { Total =312 } \\
\text { No (\%) }\end{array}$ \\
\hline Inadequate security & $150(48.1)$ & Strengthen security measures & $206(66.0)$ \\
\hline $\begin{array}{l}\text { Low socioeconomic status } \\
\text { of patients }\end{array}$ & $219(70.2)$ & $\begin{array}{c}\text { Restrict public access to } \\
\text { examination rooms }\end{array}$ & $197(63.1)$ \\
\hline $\begin{array}{l}\text { Unavailability of medical } \\
\text { equipment and medicine }\end{array}$ & $163(52.2)$ & $\begin{array}{c}\text { Provision of adequate equipment } \\
\text { and medicine }\end{array}$ & $226(72.4)$ \\
\hline Increase work load & $103(32.7)$ & Increased staff numbers & $131(42.0)$ \\
\hline Long waiting time & $123(39.4)$ & Comfortable waiting room & $142(45.5)$ \\
\hline Inadequate experience & $29(9.3)$ & $\begin{array}{c}\text { Training on violence prevention } \\
\text { and control }\end{array}$ & $108(34.6)$ \\
\hline Drug abuse by patients & $122(39.1)$ & Legislation & $211(67.6)$ \\
\hline
\end{tabular}

Table (5) showed that HCWs suggested that low socioeconomic status of patients, unavailability of medical equipment and medicine and inadequate security were the most frequent causes of violence $(70.2,52.2$ and $48.1 \%$ respectively). Other suggested causes were long waiting time (39.4\%), drug abuse of patients (39.1\%) heavy work load (32.7\%). Concerning the control and preventive measures for violence, the studied HCWs reported that provision of adequate equipment and medicine, strengthening security measures, legislation and restricting public access to examination rooms were the most frequent preventive measures $(72.4,67.6,66.0$, and $63.1 \%$ respectively). In addition, comfortable waiting room and shorter waiting time (45.5\%), increased staff numbers (42.0) and training on self-defence, violence prevention and control $(34.6 \%)$ were also suggested as preventive measures. 


\section{Discussion}

Violence in the healthcare sector is a problem specific not only to Egypt but also a significant problem worldwide. The nature of work of healthcare providers requires direct contact with patients and their relatives in a complex condition that carries the risk of exposure to violence.

The current study illustrated that the prevalence of violence incidents was $66.3 \%$ (207/312) among the studied HCWs at Al-Zahraa University Hospital with statistically significant higher prevalence among nurses $(72.5 \%)$ than physicians $(61.9 \%)(\mathrm{p}<05)$ (Table 2). This is in agreement with Algwaiz and Alghanim (2012) who found that $67.4 \%$ of HCWs were victims to violence and nurses were significantly more likely to be exposed to violence than physicians in a study conducted in Riyadh city, King Saudi Arabia. Also, nearly the same prevalence was reported in Nepal (64.9\%) (Rajbhandari, et al., 2015). However, a lower frequency of violence incidents against HCWs was observed in previous studies conducted in Italy (45\%) (Ferri et al., 2016), Turkey (44.7\%) (Pinar et al., 2015) and Saudi Arabia (45.6\%) (Al Turkil, 2016). While higher prevalence was reported in China (83.3\%) (Sun et al., 2017).This difference in the prevalence may be attributed to the difference in definition of violence, target group, and the methodology used.

Verbal violence is usually an initial phase that may either extend to physical one or be controlled. This may explain our finding that verbal abuse was the most frequent type of violence acts $(62.3 \%)$ followed by physical one $(19.8 \%)$ and sexual harassment was the least (2.6\%) (Table 2). This is in agreement with other studies done in Egypt (Abou-El-Wafa et al., 2015) in Mansoura University Hospitals, and Kabbash and El-Sallamy (2019) in Tanta Emergency Hospital in which verbal violence had the highest frequency and sexual harassment was the least. Similar findings were reported in India (Mishra et al., 2018) and China (Shi et al., 2017) where verbal abuse was as high as $75.9 \%$ and $64.9 \%$, respectively. Also in South Korea, verbal abuse was the highest (63.8\%), then physical violence $(22.3 \%)$ while sexual harassment was 19.7\%. (Park et al., 2015).In addition, in a study conducted in Ethiopia by Fute et al., (2015) verbal abuse was the most frequent type $(89.6 \%)$ then physical violence $(18.8 \%)$ while sexual 
harassment was $13 \%$. These higher frequencies of sexual harassment in both South Korean and Ethiopia studies than in our findings may be due to underreporting because of shyness related to cultural sensitivity of this issue in Egypt. On the other hand, the prevalence of physical violence was $35.6 \%$ in a study conducted in one of the Palestinian hospitals. This higher prevalence may be explained by the stress created by war and the political state in this area (Hamdan and Hamra, 2015).

The current study showed that the most common place for violence occurrence was the Emergency department (Table 2). This finding could be attributed to availability of medical services all day in emergency department, the serious condition of patients and panic state of their relatives coming to the Emergency department and insufficient communication and training skills of HCWs. The present study is in agreement with previous studies in Egypt (Abou-El-Wafa et al., 2015; and Abdellah and Salama, 2017). Also, this result is in line with a study conducted in northwest Ethiopia (2019) which found that HCWs who worked in the Emergency department were four times more likely to be exposed to WPV than those in outpatient clinics (Yenealem et al., 2019).

In the present study, nearly half $(49.8 \%)$ of the violence incidents occurred during the morning shift and about $31.4 \%$ occurred during night shift (Table 2) which is in accordance with the study conducted by Yigitbas and Genc (2019) who found that the highest level of violence $(46.9 \%)$ was reported between 08:00 am and 4:00 pm. Also in China; Lei et al., (2017) detected that the majority of violence acts against HCWs occurred during the day shift. This could be explained to be the result of congestion and increased circulation during morning shift. However, these findings are contrary to Kabbash and ElSallamy (2019) who declared that the evening and night shifts were the most frequent time for sexual violence while physical and verbal violence happened equally in all shifts. Also Bilisli and Hizay (2016) found that the evening or night shifts were the time when more than half of violent incidents occurred and explained that by defective security measures and less experience of junior staff to deal with violent situations at night and in the evening shifts.

The current study showed that 
patient relatives and friends were the most frequent perpetrators (63.3\%) followed by the patients themselves (18.8\%) ( Table 2). These results agree with the findings of earlier studies in Egypt (Abdellah and Salama, 2017), India (Mishra et al., 2018) and Ethiopia (Tiruneh et al., 2016). This could be attributed to the presence of patient's relatives during patients' management; their excessive stress from fear of loss of patients' lives also not obeying the rules regarding visiting time, in addition to a weak security system.

The studied HCWs' reaction to violence varied. Only about one quarter of the participants $(27.1 \%)$ reported the attack to the hospital administration, $24.4 \%$ tried to defend themselves and $20.3 \%$ showed negative reaction in doing nothing (Table 2). Kabbash and El-Sallamy (2019) found that the reactions of the studied nurses to physical violence were calling police, asking for help from their colleagues and self-defense, while Lei et al., (2017) showed that more than $60 \%$ of the victims reacted by victims' coping mechanisms as tolerance, patience and understanding. The variation in the response between these studies may be attributed to many factors related to cultural differences, organization's support, and work experience and training programs as stress management.

The consequences of workplace violence in the health sector have significant impact on health care providers and the effectiveness of health systems, especially in developing countries. The current study showed that frequent headache and irritable colon were the most frequent physical impacts of violence, while psychological effects were in the form of remembering the incidents $(40.1 \%$ ) and wanting to forget the incidents(35.7\%). Do not want to go to the work and job dissatisfaction were the most frequent symptoms related to work effects of violence (Table $3)$. In concurrence with our results; Kabbash and El-Sallamy (2019) found that violence may lead to negative psychological effects as feeling worried and being afraid of people, some of the participants wanted to forget the incidents and others always remembered the events. Also extreme distress in the form of repeated distributed memories, thoughts, or images of the attack, avoiding thinking or talking about the attack were found by Abou-El-Wafa et al., (2015). These negative impacts were also reported in other studies as (Ryan 
et al., 2008 and Eker et al., 2012). In line with our results Pearson and Porath (2005) found that physical violence may lead to permanent physical problems as continuous headache, chronic aches, spasm, backache or even the death of a nurse. These consequences have negative impact on the health of HCWs and on the quality of medical service. So, management programs should be provided to overcome these effects.

The prevalence of violence is significantly higher among married HCWs (54.7\%) compared to unmarried (Table 4). This finding may be explained as the responsibilities of married females regarding their families may reduce their coping abilities and make them more stressed and more vulnerable to violence incidents than unmarried HCWs.

Also, those working shifts are more likely to report workplace violence than their colleagues of day shift (Table 4). In line with this result, Sun et al., (2017) showed that in the evening or night shifts HCWs were significantly at higher risk for violence than in the morning shifts. The same finding was reported by Ariza-Montes et al., (2013). This may be due to disruption of the circadian rhythm of HCWs working shifts that increases their likelihood for fatigue, or physical illnesses and reduce their work performance that pose favourable conditions for violence.

In the present study, there was no significant association of violence with age, occupation and duration of employment (Table 4). This is in agreement with Ewis and Arafa (2015) who found that there were no significant differences among nurses who were exposed to violence regarding their age, years of experience and occupation. Contrary to these results, other studies found that less work experience and younger age are more associated with violence (Gacki-Smith et al., 2009). The difference may be related to the difference in study subjects.

The prevalence of violence was higher among HCWs with direct physical contact with patients (53.6 $\%$ ) compared to those without contact (46.4\%) but the difference was not statistically significant (Table 4). Sun et al., (2017) found that nurses providing physical direct contact with patients were more liable to violence. Also it was found in the current study that there was no significant association of violence with the number of the working staff; the prevalence of violence was higher 
among HCWs with less working staff (68.1\%) compared to those with more working staff $(22.2 \%)$ (Table 4$)$. This may be attributed to longer waiting hours for consultation and treatment that was associated with staff shortage. This is in concordance with LeBlanc and Kelloway (2002) who found that decreasing work staff was more associated with violence because it prevents HCWs from adequately coping with patients' demands.

As regards the causes of violence, HCWs suggested that low socioeconomic status of patients, shortage of medical equipment and medicine and inadequate security were the most frequent causes of violence. Other suggested causes as long waiting time, drug abuse of patients and increase work load (Table 5). A study conducted in Abha city by AlSaleem et al., (2018) found overcrowding, long waiting time, heavy workload, staff shortage and lack of security were the main causes of workplace violence. Another study conducted by Mishra et al., (2018) detected that heavy workload on healthcare staff, high patient expectation and drug abuse were the most important factors contributing to violence. Also, shortage of staff increased waiting time and unmet patients' demands were reported as the most frequent causes of violence by Algwaiz and Alghanim, 2012. In addition, lack of knowledge and skills to handle the situations were recorded as the reason for violent incidents (Kumar et al., 2016).

The studied HCWs reported that provision of adequate equipment and medicine, security measures, legislation and restricting public access to examination rooms were the most frequent preventive measures. In addition, comfortable waiting rooms, increased staff numbers, training on violence prevention and control, were suggested as preventive measures (Table 5). Similar suggested measures were reported by (Koukia et al., 2013 and Kumar et al., 2016). In Turkey, establishment of employee security units and legislation have been implemented to prevent violence against healthcare professionals (Attar, 2017).

\section{Conclusion and Recommendations}

Based on the results of the present study, we conclude that WPV is highly prevalent among the studied HCWs. Being a nurse, married, and working in Emergency departments and shift time were associated with the violence. In spite of the fact that most violence 
incidents were verbal, physical violence was common and the victims suffered psychological and physical effects in addition to the negative impacts towards work. The current study highlighted the need to develop management strategy to overcome WPV against HCWs. This strategy should include implementing a programme for reporting, analysis and management, legislation enforcement, proper working environment with adequate security. The HCWs should have adequate training on how to communicate and deal with aggressive people. Public education is also essential.

\section{Conflicts of Interest}

None

\section{Funding}

None

\section{Acknowledgment}

Many thanks are due for all participants for their time in sharing to this work.

\section{References}

1- Abdellah RF and Salama KM (2017): Prevalence and risk factors of workplace violence against health care workers in emergency department in Ismailia, Egypt. Pan Afr Med J; 26:21. doi: http:// dx.doi.org/10.11604/pamj.2017.26.21.10837 PMID: 28451000
2- Abou-El-Wafa HS, El-Gilany AH, Abd-ElRaouf SE, Abd-Elmouty SM, El-Sayed H et al.(2015): Workplace violence against emergency versus non-emergency nurses in Mansoura university hospitals. Egypt J Interpers Violence; 30(5):857-72.doi: https://doi. org/10.1177/0886260514536278

3- Algwaiz WM and Alghanim SA (2012): Violence exposure among health care professionals in Saudi public hospitals. A preliminary investigation. Saudi Med J; 33(1): 76-82.doi:https://www.ncbi. nlm.nih.gov/pubmed/22273653

4- Alkorashy HA and Al Moalad FB (2016): Workplace violence against nursing staff in a Saudi university hospital. Int Nurs Rev; 63(2): 226- 32. doi:10.1111/inr. 12242

5- Al-Turki1 N (2016): Violence against health workers in family medicine centres. J Multidiscip Health; 9:257-66. doi: https://www.ncbi.nlm. nih.gov/pubmed/27330300

6- Alsaleem SA, Alsabaani A, Alamri RS, Hadi RA, Alkhayri, et al., (2018): Violence towards healthcare workers: A study conducted in Abha City, Saudi Arabia. J Fam Community Med; 25(3):188-93. doi :http://dx.doi.org/10.4103/ jfcm.JFCM_170_17 PMID: 30220849

7- Ariza-Montes A, Muniz NM, Montero-Simó MJ and Araque-Padilla RA (2013): Workplace bullying among healthcare workers. Int J Environ Res Public Health; 10(8):3121-39.doi:https:// doi.org/10.3390/ijerph10083121

8- Attar GE (2017): Violence towards Physicians in Turkey: A Grounded theory analysis. Turk J Sociol; 37(1): 157-78.doi: 10.16917/ iusosyoloji.331332. Availableathttps://dergipark. org.tr/tr/pub/iusosyoloji/issue/35798/401007

9- Basilua A, Lukuke H, Nlandu R, Kaj F, Masamitsu E et al., (2015): Workplace violence towards Congolese health care workers: A survey of 436 healthcare facilities in Katanga province, Democratic Republic of Congo. J Occup Health; 57: 69-80.doi: 10.1539/joh.14-0111-OA

10- Bilisli Y and Hizay D (2016): Violence against healthcare workers in workplace: A case of 
university hospital. IJSS; 52: 473-86.

11-Boafo I and Hancock P (2017): Workplace violence against nurses: a cross-sectional descriptive study of Ghanaian nurses. Sage open, 7(1):9. Available at https://doi. org/10.1177\%2F2158244017701187

12-Cheung T, Lee PH and Yip PS (2017): Workplace violence toward physicians and nurses: prevalence and correlates in Macau. Int $\mathbf{J}$ Environ Res Public Health; 14(8). http://dx.doi. org/10.3390/ijerph14080879 PMID: 28777333

13- Eker HH, Özder A, Tokaç M, Topçu I and Tabu A (2012): Aggression and violence towards health care providers, and effects thereof. Arch Psychiatr Psychot; 4:19-29.

14-Ewis AA and Arafa AE (2015): Violence against nurses: an epidemiological study for nurses in municipal, health insurance and university hospitals of Beni-Suef Governorate, Egypt. EJOM; 38 (1): 1-22.doi: 10.21608/ EJOM.2014.785

15-Fallahi-Khoshknab M, Oskouie F, Najafi F, Ghazanfari N, Tamizi Z ,et al. (2016): Physical violence against health care workers: A nationwide study from Iran. Iran $\mathrm{J}$ Nurs Midwifery Res; 21(3): 232.doi: 10.4103/17359066.180387

16-Ferri P, Antoni C, Silvestri M and Di Lorenzo P (2016): Workplace violence in different settings and among various health professionals in Italian general hospitals: a cross sectional study. Psychol Res Behav Manag; 9: 263-75. doi: 10.2147/ PRBM.S114870

17-Fujita S, Ito S, Seto K, Kitazawa T, Matsumoto K et al., (2012): Risk factors of workplace violence at hospitals in Japan. J Hosp Med; 7(2):79-84. doi: http://dx.doi.org/10.1002/jhm.976 PMID: 22058040

18-Fute M, Mengesha ZB, Wakgari N and Tessema GA (2015): High prevalence of workplace violence among nurses working at public health facilities in Southern Ethiopia. BMC Nurs; 14:14- 9 .

19-Gacki-Smith J, Juarez AM, Boyett L, Homeyer
C, Robinson L et al., (2009): Violence against nurses working in US emergency departments. J Nurs Adm; 9(7/8):340-9.doi: 10.1097/ NNA.0b013e3181ae97db

20-Hamdan M and Hamra A (2015): Workplace violence towards workers in the emergency departments of Palestinian hospitals: a cross sectional study. Hum Resour Health; 13:28.doi: 10.1186/s12960-015-0018-2

21-Hasan M, Hassan M, Bulbul M, Joarder T, and Chisti M (2018): Workplace violence in health sector of Bangladesh. BMC Res Notes 11 (1): 702.doi: https://doi.org/10.1186/s13104018-3795-6

22-ILO (The International Labour Office), ICN (International Council of Nurses), WHO (World Health Organization) and PSI (Public Services International) (2003): Joint Programme on Workplace Violence in the Health Sector Confidential Survey. Adapted from WHO definition of violence, Alberta Association of Registered Nurses, ILO - Violence at Work, Human Rights Act, UK, Irish Nurses Organization, Human Rights Act, UK. Geneva. Available at:https://www.who.int/violence injury_prevention/violence/interpersonal/en/ WVmanagementvictimspaper.pdf.

23-Kabbash IA and El-Sallamy R (2019): Violence against health care workers in emergency hospital, Tanta University, Egypt. EJOM; 43(2):215-28.doi: 10.21608/ejom.2019.31424

24-Koukia E, Mangoulia P, Gonis N, and Katostaras $T$ (2013): Violence against health care staff by patient's visitor in general hospital in Greece: Possible causes and economic crisis. OJN; 3:217.doi: 10.4236/ojn.2013.38A004

25-Kumar M, Verma M, Das T, Pardeshi G, Kishore $\mathrm{J}$,et al., (2016): A study of workplace violence experienced by doctors and associated risk factors in a tertiary care hospital of south Delhi, India. J Clin Diagnostic Res; 10(11): 6-10. doi: 10.7860/JCDR/2016/22306.8895

26-LeBlanc M and Kelloway E (2002): Predictors and outcomes of workplace violence and 
aggression. JAP; 87: 444-53. doi: 10.1037/00219010.87.3.444

27- Lei Shi, Danyang Z, Chenyu Z, LibinYang, Tao Sun, et al. (2017): A cross-sectional study on the prevalence and associated risk factors for workplace violence against Chinese nurses. BMJ Open; 7(6):e013105. doi: 10.1136/ bmjopen-2016-013105

28- Mishra S, Chopra D, Jauhari N, Ahmad A, and Kidwai N (2018): Violence against health care workers: a provider's (staff nurse) perspective. Int J Community Med Public Health; 5(9):41404148.doi: 10.18203/2394-6040.ijcmph20183609

29-Pandey M, Bhandari T, and Dangal G (2018): Workplace violence and its associated factors among nurses. J Nepal Health Res Counc ; 15(3):235-6.doi: 10.3126/JNHRC.V15I3.18847

30-Park M, Cho SH and Hong HJ (2015): Prevalence and perpetrators of workplace violence by nursing unit and the relationship between violence and the perceived work environment. J Nurs Scholarsh; 47(1):87-95.doi: https://doi. org/10.1111/jnu.12112

31- Pearson CM and Porath CL (2005): On the nature, consequences and remedies of workplace incivility: No time for "nice"? Think again. Academy of Management Executive; 19(1):718.doi: 10.5465/AME.2005.15841946

32-Pinar T, Acikel C, Pinar G and Karabulut E (2015): Workplace violence in the health sector in Turkey: a national study. J Interpers Violence;(32):15.doi: $10.1177 / 0886260515591976$

33-Rajbhandari R, Subedi S and Kaphle HP (2015): Workplace violence against health workers: a cross-sectional study from Baglung district, Nepal. Int J Health Sci Res; 5(2):274-
81.Available at: https://www.researchgate.net/ publication/272485109

34-Raosoft Inc (2004): Sample Size Calculator. Available online: http://www.raosoft.com/ samplesize.html.

35-Ryan EP, Aaron J, Burnette ML, Warren J, Burket R, et al. (2008): Emotional responses of staff to assault in a pediatric state hospital. J Am Acad Psychiatry Law; 36:360-8.

36-ShiL, Zhang D, Zhou C, Yang L, Sun T, Hao T, et al. (2017): A cross-sectional study on the prevalence and associated risk factors for workplace violence against Chinese nurses. BMJ open; 7(6), e013105.doi: http://dx.doi. org/10.1136/bmjopen-2016-013105

37- Sun P, Zhang X, Sun Y, MaH, Jiao M, et al., (2017). Workplace violence against health care workers in North Chinese Hospitals: A crosssectional survey. Int $\mathrm{J}$ Environ. Res Public Health; 14: 1-10.doi: 10.3390/ijerph14010096

38-Tiruneh BT, Bifftu BB, Tumebo AA, Kelkay M M, Anlay D Z, et al. (2016): Prevalence of workplace violence in Northwest Ethiopia: a multivariate analysis. BMC nursing; 15(1): 42.

39-Yenealem DG, Woldegebriel MK, Olana AT and MekonnenTH (2019): Violence at work: determinants \& prevalence among health care workers, northwest Ethiopia: an institutional based cross sectional study. Ann Occup Environ Med; (31): 8. doi: 10.1186/s40557-019-0288-6

40-Yigitbas C and Genc F (2019): Knowledge, Attitude and Behavior of Healthcare Professionals for Physical Violence. JIHSAM; 5(8):1-18.Available at: https://dergipark.org.tr/ en/pub/jihsam/issue/44910/524113 
